\title{
ANTIMICROBIAL ACTIVITY OF SOME MEDICINAL PLANTS FROM THE CERRADO OF THE CENTRAL- WESTERN REGION OF BRAZIL
}

\section{Ivana Maria Póvoa Violante ${ }^{1,4}$, Lidilhone Hamerski ${ }^{1}$, Walmir Silva Garcez ${ }^{1}$, Ana Lucia Batista ${ }^{1}$, Marilene Rodrigues Chang $^{2}$, Vali Joana Pott ${ }^{3}$, Fernanda Rodrigues Garcez ${ }^{1}$ *}

${ }^{1}$ Departamento de Química, Universidade Federal de Mato Grosso do Sul, Campo Grande, MS, Brasil; ${ }^{2}$ Departamento de Farmácia e Bioquímica, Universidade Federal de Mato Grosso do Sul, Campo Grande, MS, Brasil; ${ }^{3}$ Departamento de Biologia, Universidade Federal de Mato Grosso do Sul, Campo Grande, MS, Brasil; ${ }^{4}$ Departamento de Farmácia, Universidade de Cuiabá, Cuiabá, MT, Brasil.

Submitted: April 08, 2011; Returned to authors for corrections: January 17, 2012; Approved: June 07, 2012.

\begin{abstract}
Ethanol extracts from six selected species from the Cerrado of the Central-Western region of Brazil, which are used in traditional medicine for the treatment of infectious diseases and other medical conditions, namely Erythroxylum suberosum St. Hil. (Erythroxylaceae), Hyptis crenata Pohl. ex Benth. (Lamiaceae), Roupala brasiliensis Klotz. (Proteaceae), Simarouba versicolor St. Hil. (Simaroubaceae), Guazuma ulmifolia Lam. (Sterculiaceae) and Protium heptaphyllum (Aubl.) March. (Burseraceae), as well as fractions resulting from partition of these crude extracts, were screened in vitro for their antifungal and antibacterial properties. The antimicrobial activities were assessed by the broth microdilution assay against six control fungal strains, Candida albicans, C. glabrata, C. krusei, C. parapsilosis, C. tropicalis and Cryptococcus neoformans, and five control Gram-positive and negative bacterial strains, Escherichia coli, Enterococcus faecalis, Klebsiella pneumoniae, Pseudomonas aeruginosa and Staphylococcus aureus. Toxicity of the extracts and fractions against Artemia salina was also evaluated in this work. All plants investigated showed antimicrobial properties against at least one microorganism and two species were also significantly toxic to brine shrimp larvae. The results tend to support the traditional use of these plants for the treatment of respiratory and gastrointestinal disorders and/or skin diseases, opening the possibility of finding new antimicrobial agents from these natural sources. Among the species investigated, Hyptis crenata, Erythroxylum suberosum and Roupala brasiliensis were considered the most promising candidates for developing of future bioactivity-guided phytochemical investigations.
\end{abstract}

Key words: Antifungal; Antibacterial; Antimicrobial; Artemia salina; Cerrado

INTRODUCTION

In spite of the increasing progress made in the microbiology area, infectious diseases are still a significant cause of morbidity and mortality worldwide, where drug-resistant strains of pathogenic bacteria and fungi are increasingly

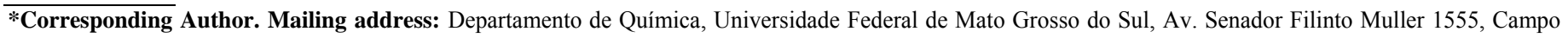
Grande, MS, 79074-900, Brasil.; Tel.: +55-67-33453579 Fax: +55-67-33453552.; E-mail: fernanda.garcez@,ufms.br 
prevalent (9). Epidemics due to the limitations of currently available therapy pose an enormous threat to public health and the problem worsens when the colonization of bacteria and fungi reaches the especially high-risk group of immunologically compromised patients $(5,9)$. The need for the development of more effective and safe antimicrobial agents has stimulated multidisciplinary investigations focused on plant-derived compounds as source of new leading antimicrobial drugs $(15,23)$. So, preliminary in vitro screening for antimicrobial activity of plant extracts may serve as a guide to select those with significant activity as potential resources for such new drugs and therefore, as promising candidates for further phytochemical and pharmacological research.

The Cerrado Domain is the second largest of Brazil's major biomes, after Amazonia, comprising more than 7,000 vascular plant species (13). Due to its notable diverse flora, there has been an increasing interest in the research on medicinal plants endemic to the Cerrado as a source of bioactive compounds.

In the present work, ethanol extracts from six selected plants endemic to the Cerrado of the Central-West region of Brazil traditionally used in folk medicine for the treatment of infectious diseases and other medical conditions (Table 1) (6, $12,26)$ in addition to 24 fractions resulting from the partition of the initial ethanol extracts, were evaluated for their antimicrobial activities in vitro against Candida albicans, $C$. glabrata, C. krusei, C. parapsilosis, C. tropicalis, Cryptococcus neoformans, Escherichia coli, Enterococcus faecalis, Klebsiella pneumoniae, Pseudomonas aeruginosa and Staphylococcus aureus, as well as for toxicity against Artemia salina.

\section{MATERIALS AND METHODS}

\section{Plant material}

Plant material was collected in June 2006 in Cuiabá, Mato Grosso, Brazil and identified by Dr. Miramy Macedo (Universidade Federal de Mato Grosso, Cuiabá, MT, Brazil) and/or by MSc. Vali J. Pott (Universidade Federal de Mato Grosso do Sul, MS, Brazil). Voucher specimens were deposited at the Central Herbarium, Universidade Federal de Mato Grosso, MT, Brazil and/or at the CGMS Herbarium, Universidade Federal de Mato Grosso do Sul, MS, Brazil (Hyptis crenata Pohl. ex Benth.) (Table 1).

Table 1. Botanical identification, folk indication and parts used of the medicinal plants studied.

\begin{tabular}{|c|c|c|c|c|c|}
\hline Family & $\begin{array}{c}\text { Botanical } \\
\text { name }\end{array}$ & $\begin{array}{c}\text { Voucher specimen } \\
\text { (Registration number) }\end{array}$ & Popular name & Collected part & $\begin{array}{c}\text { Therapeutic } \\
\text { indication }\end{array}$ \\
\hline Burseraceae & $\begin{array}{c}\text { Protium } \\
\text { heptaphyllum (Aubl.) } \\
\text { March. }\end{array}$ & $23787 / 23788$ & Amescla, Breu & Stem bark & $\begin{array}{l}\text { Respiratory disorders } \\
(12)\end{array}$ \\
\hline Erythroxylaceae & $\begin{array}{c}\text { Erythroxylum } \\
\text { suberosum St. Hil. }\end{array}$ & 23795 & Cabelo-de-negro & Stem bark & $\begin{array}{l}\text { Abortive and } \\
\text { inflammatory processes } \\
(26)\end{array}$ \\
\hline Lamiaceae & $\begin{array}{l}\text { Hyptis crenata Pohl. } \\
\text { ex Benth. }\end{array}$ & 28968 & $\begin{array}{l}\text { Hortelã-do- } \\
\text { campo }\end{array}$ & Whole plant & $\begin{array}{l}\text { Respiratory and intestinal } \\
\text { disorders }(6,26) \text { and } \\
\text { abdominal pain }(6)\end{array}$ \\
\hline Proteaceae & $\begin{array}{c}\text { Roupala brasiliensis } \\
\text { Klotz. }\end{array}$ & 23756 & $\begin{array}{l}\text { Carne-de-vaca, } \\
\text { Bosta-de-urubu }\end{array}$ & Stem bark & $\begin{array}{l}\text { Intestinal and non- } \\
\text { specific blood disorders } \\
(26)\end{array}$ \\
\hline Simaroubaceae & $\begin{array}{c}\text { Simarouba versicolor } \\
\text { St. Hil. }\end{array}$ & 23777 & $\begin{array}{l}\text { Mata-cachorro, } \\
\text { Pé-de-perdiz }\end{array}$ & Stem bark & $\begin{array}{l}\text { Non-specific blood } \\
\text { disorders, infected } \\
\text { wounds (12) and uterine } \\
\text { and ovarian inflammation } \\
(6)\end{array}$ \\
\hline Sterculiaceae & $\begin{array}{l}\text { Guazuma ulmifolia } \\
\text { Lam. }\end{array}$ & 23795 & $\begin{array}{l}\text { Mutamba, Chico- } \\
\text { magro }\end{array}$ & Stem bark & $\begin{array}{l}\text { Skin diseases and gastric } \\
\text { ulcer }(6)\end{array}$ \\
\hline
\end{tabular}




\section{Preparation of plant extracts}

Air-dried and powdered plant materials, approximately from 400 to $1265 \mathrm{~g}$, were extracted with ethanol at room temperature for five days. After concentration in vacuo (Fisaton -Model 802), the residues obtained from the corresponding crude ethanol extracts were partitioned between methanol-water (9:1) and hexane. The methanol-water (9:1) phase was further diluted to methanol-water (1:1) and subsequently partitioned with dichloromethane and ethyl acetate. Portions of each dry ethanol extract, as well as the hexane, dichloromethane, ethyl acetate and the remaining methanol-water $(1: 1)$ phases, were tested for antifungal and antibacterial activities and toxicity against brine shrimp larvae.

\section{Antimicrobial activity assay}

Strains from the American Type Culture Collection (ATCC), Rockville, MD, USA were used for the antifungal and antibacterial evaluations: Candida albicans (ATCC 90028), C. tropicalis (ATCC 760), C. glabrata (ATCC 9030), C. krusei (ATCC 6258), C. parapsilosis (ATCC 22019), Cryptococcus neoformans (ATCC 32045), Escherichia coli (ATCC25922), Pseudomonas aeruginosa (ATCC 27853), Klebsiella pneumoniae (ATCC700603), Enterococcus faecalis (ATCC 29218) and Staphylococcus aureus (ATCC 25923), available at the University Hospital Center, Division of Biochemical Pharmacy, Section of Clinical Analyses, Universidade Federal de Mato Grosso do Sul. Amphotericin B and Chloramphenicol (Sigma Chemical Co.) were used as the reference antimycotic and antibacterial controls, respectively, on the basis of their use as reference antimicrobial compounds in bioassays with crude medicinal plant extracts $(2,7,14,17$, $20,25)$.

The antifungal and antibacterial activities were determined using microbroth dilution assays in 96-well microplates, in duplicate, following the guidelines of the Clinical and Laboratory Standards Institute $(21,22)$. The lowest concentration of extract or fraction at which no fungal or bacterial growth was observed after incubation was recorded as the minimum inhibitory concentration (MIC).

\section{General toxicity (brine shrimp lethality) assay}

Brine shrimp (Artemia salina) (Maramar) lethality test was performed with crude extracts and their respective fractions in triplicate, according to Meyer et al. (19), using quinidine sulphate (Merck) as a positive control. LD $_{50}$ values in $\mu \mathrm{g} / \mathrm{ml}$ were determined using probit analysis.

\section{RESULTS}

A total of six crude ethanol extracts, as well as the hexane, dichloromethane, ethyl acetate and ethanol-water 1:1 soluble fractions resulting from the partition of the initial ethanol extracts from Erythroxylum suberosum, Guazuma ulmifolia, Hyptis crenata, Protium heptaphyllum, Roupala brasiliensis and Simarouba versicolor were evaluated for their biological activities.

Screening results for antifungal and antibacterial activities are depicted in Table 2. All the crude extracts tested were shown to be active against Cryptococcus neoformans and Candida krusei, exhibiting MIC values in the range of 31.3$500 \mu \mathrm{g} / \mathrm{ml}$. Among the plant extracts, the broadest spectrum of action was depicted by that of $R$. brasiliensis which inhibited all the fungal strains tested, showing the strongest activities against Candida glabrata and C. krusei (MIC $=15.6 \mu \mathrm{g} / \mathrm{ml}$ and $31.3 \mu \mathrm{g} / \mathrm{ml}$, respectively). Extracts of two of the five remaining species (H. crenata and P. heptaphyllum) were found to be active (MIC values of $125 \mu \mathrm{g} / \mathrm{ml}$ ) against two fungi, C. krusei and Cryptococcus neoformans while those of E. suberosum and G. ulmifolia displayed a MIC of $125 \mu \mathrm{g} / \mathrm{ml}$ only against $C$. krusei.

Regarding the antifungal activities of the fractions resulting from the partition of the crude ethanol extracts of the six plants evaluated in this work, that with the highest polarity (methanol-water 1:1) obtained from $R$. brasiliensis not only was the most active among all the fractions assayed in this work, with MIC values as low as $15.6 \mu \mathrm{g} / \mathrm{ml}$ (against $C$. 
glabrata), but also showed the broadest effect against strains of Candida. Concerning the activity against C. krusei, a significant result was also observed for the hydromethanolic fraction of $S$. versicolor $(\mathrm{MIC}=31.3 \mu \mathrm{g} / \mathrm{ml}$ ), suggesting that the most polar constituents of these two plants are the main contributors to the antifungal activity against these strains.

Table 2. Antifungal and antibacterial activities (MIC values in $\mu \mathrm{g} / \mathrm{ml}$ ) of plant extracts and their fractions.

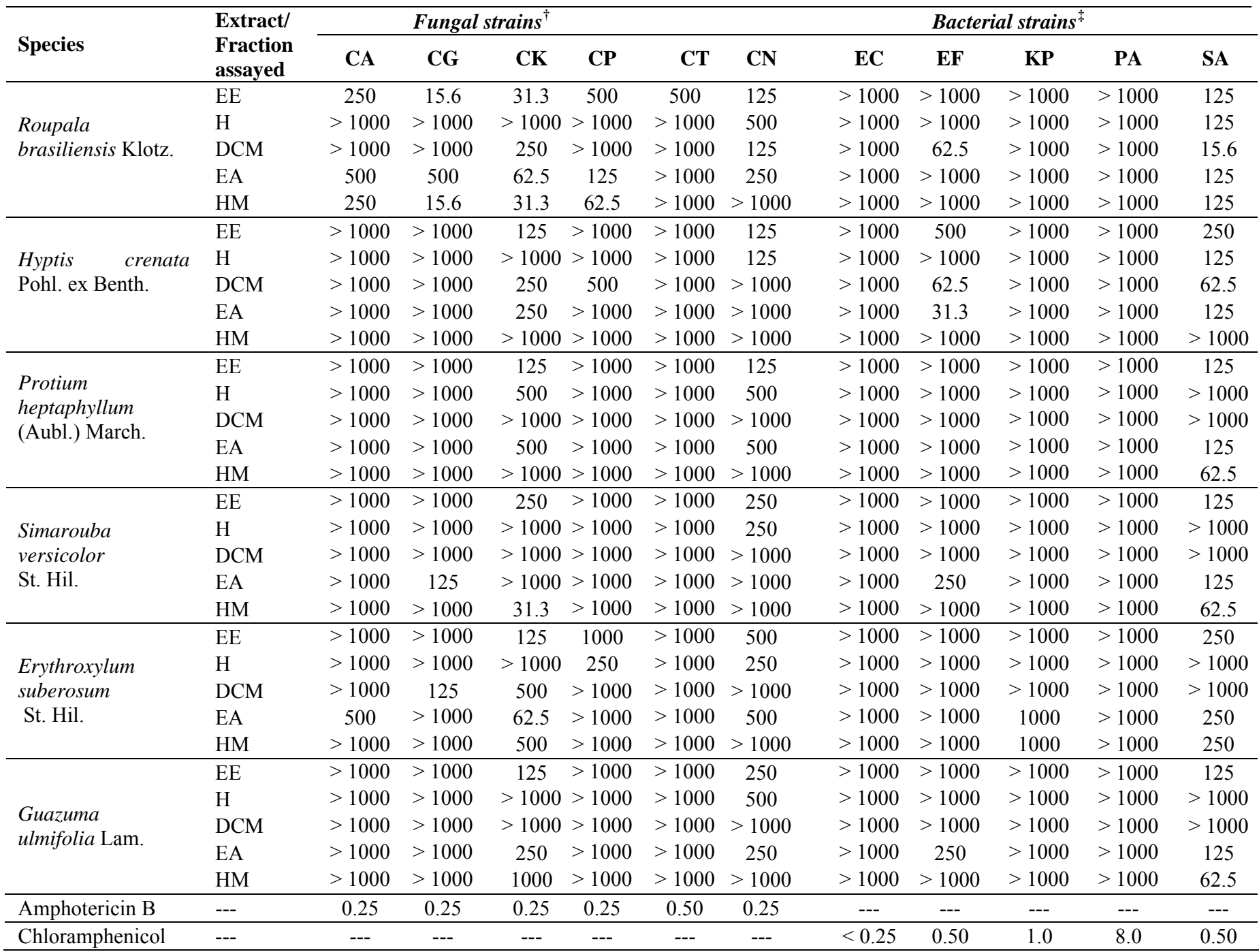

*EE, Ethanol Extract; H, Hexane fraction; DCM, Dichloromethane fraction; EA, Ethyl acetate fraction; HM, Hydromethanolic fraction.

${ }^{\dagger}$ CA, Candida albicans ATCC 90028; CG, C. glabrata ATCC 9030; CK, C. krusei ATCC 6258; CP, C. parapsilosis ATCC 22019; CT, C. tropicalis ATCC 760; CN, Cryptococcus neoformans ATCC 32045.

${ }^{\ddagger}$ EC, E. coli ATCC 25922; EF, E. faecalis ATCC29218; KP, K. pneumoniae ATCC 700603; PA, P. aeruginosa ATCC 27853; SA, S. aureus ATCC 25923.

Breakpoints for chloramphenicol (Sensitive $\leq 8 \mu \mathrm{g} / \mathrm{ml}$ and Resistant $\geq 32 \mu \mathrm{g} / \mathrm{ml}$ ) and amphotericin B (Sensitive $\leq 1 \mu \mathrm{g} / \mathrm{ml}$ and Resistant $>1 \mu \mathrm{g} / \mathrm{ml}$ ).

Some other species also displayed significant antifungal activities which were concentrated in one specific fraction after the partition procedures performed with the crude ethanol extracts, such as the effects of the less polar (hexane) fraction of $H$. crenata against Cryptococcus neoformans (MIC $=125$ $\mu \mathrm{g} / \mathrm{ml}$ ), of the intermediate polar (dichloromethane) fraction of
E. suberosum against C. glabrata $(\mathrm{MIC}=125 \mu \mathrm{g} / \mathrm{ml})$ and also of the polar (ethyl acetate) fractions of $S$. versicolor and $E$. suberosum against C. glabrata and C. krusei, respectively (MICs $=125 \mu \mathrm{g} / \mathrm{ml}$ and $62.5 \mu \mathrm{g} / \mathrm{ml}$, respectively).

In this study, the crude plant extracts were shown to be more active against Gram-positive bacteria than against Gram- 
negative ones. The Gram-positive S. aureus was inhibited to some extent by all extracts assayed (MIC values of at least 125 $\mu \mathrm{g} / \mathrm{ml}$ ), being worthy of mention the specific effects of $P$. heptaphylum against this microorganism. Regarding the activities against $S$. aureus presented by the fractions obtained from the partition procedures of the crude extracts, it is remarkable the low MIC value of the dichloromethane fraction of $R$. brasiliensis $(15.6 \mu \mathrm{g} / \mathrm{ml})$. Noteworthy are also the MICs of the dichloromethane fraction of $H$. crenata $(62.5 \mu \mathrm{g} / \mathrm{ml})$ and of the hydromethanolic fractions of $P$. heptaphyllum, $S$. versicolor and G. ulmifolia $(62.5 \mu \mathrm{g} / \mathrm{ml})$. Some of the fractions resulting from the partition of the crude ethanol extracts of four plant species (H. crenata, G. ulmifolia, R. brasiliensis and S. versicolor) were also active against the other Gram-positive bacterium employed in this work, Enterococcus faecalis. In particular, the strongest activities against this bacterial strain were observed for the dichloromethane and ethyl acetate fractions obtained from $H$. crenata $(\mathrm{MIC}=62.5$ and 31.3 $\mu \mathrm{g} / \mathrm{ml}$, respectively) and the dichloromethane fraction of $R$. brasiliensis ( $\mathrm{MIC}=62.5 \mu \mathrm{g} / \mathrm{ml}$ ) in comparison with both the hexane and the hydroalcoholic fractions. So, the notable activities exhibited by the dichloromethane phases of $R$. brasiliensis and $H$. crenata against both $S$. aureus and $E$. faecalis suggest that the intermediate polar constituents of these two plants are potentially-antibacterial agents against these two strains. On the other hand, neither crude extracts of all plant species nor their respective fractions displayed any significant activity against the Gram-negative bacterial strains evaluated in this work, Escherichia coli, Klebsiella pneumoniae and Pseudomonas aeruginosa (MICs $\geq 1000$ $\mu \mathrm{g} / \mathrm{ml})$.

The preliminary assessment of toxicity of the extracts and their fractions was done using the brine shrimp (Artemia salina) lethality bioassay (19). Four among the six species screened in the present study (H. crenata, S. versicolor, G. ulmifolia and $P$. heptaphyllum) were found to be non-toxic to A. salina since they showed $\mathrm{LD}_{50}$ values higher than 1000 $\mu \mathrm{g} / \mathrm{ml}$, while the toxicity presented by the extracts of $R$. brasiliensis and E. suberosum, as well as by some of their fractions were noteworthy, particularly that of the intermediate polar dichloromethane fraction of E. suberosum which was found to be highly toxic (Table 3).

Table 3. Toxicity of plant extracts and their fractions against brine shrimp (Artemia salina) larvae.

\begin{tabular}{ccc}
\hline Species & $\begin{array}{c}\text { Extract/fractions } \\
\text { assayed }\end{array}$ & LD $_{\text {50 }}(\mu \mathbf{g} / \mathbf{m l})$ \\
\hline & EE & 29.7 \\
Erythroxylum suberosum St. Hil. & H & $>1000$ \\
& DCM & 1.3 \\
& EA & 476.9 \\
& HM & $>1000$ \\
\hline & EE & 336.2 \\
Roupala brasiliensis Klotz. & H & $>1000$ \\
& DCM & $>1000$ \\
Quinidine sulphate & HM & 446.3 \\
\hline
\end{tabular}

*EE, Ethanol Extract; H, Hexane fraction; DCM, Dichloromethane fraction; EA, Ethyl acetate fraction; HM, Hydromethanolic fraction. Extracts and fractions of Hyptis crenata, Protium heptaphyllum, Simarouba versicolor and Gazuma ulmifolia showed $\mathrm{LD}_{50}$ values $>1000 \mu \mathrm{g} / \mathrm{ml}$.

\section{DISCUSSION}

The results obtained in the present study for Roupala brasiliensis are particularly noteworthy, not only for the antimicrobial activity presented by its crude extract and/or fractions but also because to date there are no records on 
bioactive constituents of plants of this genus.

Some species of the genus Hyptis are known for their significant ethnopharmacological properties, including antimicrobial activities $(8,10,24)$, while crude extracts of Erythroxylum catuaba da Silva ex Hamet have shown antibacterial activities in vivo against Escherichia coli and Staphylococcus aureus (15). No reports on biological activities on Hyptis crenata and Erythroxylum suberosum have however been described, so this is the first report on the antifungal and antibacterial activities of these species.

Few records have been found related to antimicrobial properties from members of Simarouba, such as antibacterial activity shown by Simarouba glauca DC. against some enterobacteria (3) and potentially-antimicrobial alkaloids obtained from S. cuspidata Spruce ex Engl. (11) and so this is the also the first report on the antibacterial and antifungal activities of Simarouba versicolor.

No antifungal properties from plants of the genus Guazuma have been described so far. In a previous study (4) the hexane and methanol extracts of the bark of a specimen of Guazuma ulmifolia collected in Belize were considered to be active against Escherichia coli (ATCC25922) and Pseudomonas aeruginosa (ATCC 27853), respectively, although showing high values of MIC $(2500 \mu \mathrm{g} / \mathrm{ml})$. In the present work, the crude ethanol extract was shown to inhibit the growth of $S$. aureus (MIC $=125 \mu \mathrm{g} / \mathrm{ml}$ ) while the ethyl acetate and hydromethanolic fractions were active to some extent against $E$. faecalis (MIC $=250 \mu \mathrm{g} / \mathrm{ml}$ and $1000 \mu \mathrm{g} / \mathrm{ml}$, respectively).

Finally, the results obtained in this work for the stem bark of Protium heptaphyllum corroborate the antimicrobial activities described for the essential oils obtained from the resin of other individuals of this species collected in the Northeast of Brazil (1) and render the specimen occurring in the Central-Western region of Brazil interesting for future research as well.

Since the extracts and fractions of $H$. crenata, $S$. versicolor, G. ulmifolia and P. heptaphyllum did not show any toxic effect against brine shrimp larvae, they can be considered as promising candidates from which relatively safe antimicrobial constituents might be obtained in future bioactivity-guided phytochemical investigations, particularly $H$. crenata. Due to the significant toxicity presented by $R$. brasiliensis and E. suberosum to Artemia salina, the medicinal use of these two plants is not recommended at least until further safety studies are carried out. On the other hand, the brine shrimp lethality test has been shown to have a good correlation with cytotoxic activity in some human solid tumors and, therefore, it has been widely employed as a leading guide to the isolation of cytotoxic compounds in bioassay-guided fractionation of plant extracts (18). So, R. brasiliensis and $E$. suberosum can be also of great value in the search for potential cytotoxic agents from these species.

In addition to support the traditional use of these plants for the treatment of respiratory and gastrointestinal disorders and/or skin diseases, the results of this preliminary investigation open the possibility of finding new antimicrobial and/or potential antitumor agents from these natural sources.

\section{ACKNOWLEDGEMENTS}

The authors wish to thank Dr. Miramy Macedo for assistance in the identification of the plant material. The authors are grateful to Fundação de Apoio ao Desenvolvimento do Ensino, Ciência e Tecnologia do Estado de Mato Grosso do Sul (FUNDECT-MS), Universidade Federal de Mato Grosso do Sul (UFMS) and Universidade de Cuiabá (UNIC) for their financial support.

\section{REFERENCES}

1. Bandeira, P.N.; Fonseca, A.M.; Costa, S.M.O.; Lins, M.U.D.S.; Pessoa, O.D.L.; Monte, F.J.Q.; Nogueira, N.A.P.; Lemos, T.L.G. (2006). Antimicrobial and antioxidant activities of the essential oil of resin of Protium heptaphyllum. Nat. Prod. Comm. 1, 117-20.

2. Bouzada, M.L.M.; Fabrin, R.L.; Nogueira, M.; Konno, T.U.P.; Duarte, G.G.; Scio, E. (2009). Antibacterial, cytotoxic and phytochemical screening some traditional medicinal plants in Brazil. Pharm. Biol. 47, 
44-52.

3. Caceres, A.; Cano, O.; Samayoa, B.; Aguilar, L. (1990). Plants used in Guatemala for the treatment of gastrointestinal disorders. 1. Screening of 84 plants against enterobacteria. J. Ethnopharmacol. 30, 55-73.

4. Camporese, A.; Balick, M.J.; Arvigo, R.; Espósito, R.G.; Morsellino, N.; de Simone, F.; Tubaro, A. (2003). Screening for anti-bacterial activity of medicinal plants from Belize (Central America). J. Ethnopharmacol. 87, 103-107.

5. Cowen, L.E. (2008). The evolution of fungal drug resistance: modulating the trajectory from genotype to phenotype. Nature 6, 187-198.

6. De la Cruz, M.G. (1997). Plantas medicinais utilizadas por raizeiros: uma abordagem etnobotânica no contexto da saúde e doença. Cuiabá, Brasil, 110p. (M.Sc. Dissertation. Instituto de Saúde Coletiva. (UFMT).

7. Duarte, M.C.T.; Figueira, F.S., Pereira, B.; Magalhães. P.M. Delarmina, C. (2004). Atividade antimicrobiana de extratos hidroalcoólicos de espécies da coleção de plantas medicinais CPQBA/UNICAMP. Rev. Bras. Farmacog. 14, 06-08.

8. Falcão, D.Q.; Menezes, F.S. (2003). The Hyptis genus: an ethnopharmacological and chemical review. Rev. Bras. Farm. 84, 69-74.

9. Fischbach, M.A.; Walsh, C.T. (2009). Antibiotics for Emerging Pathogens. Science 325, 1089-1093.

10. Fragoso-Serrano, M.; Gibbons, S.; Pereda-Miranda, R. (2005). AntiStaphylococcal and cytotoxic compounds from Hyptis pectinata. Plant. Med. 71, 278-280.

11. Giesbrecht, A.M.; Gottlieb, H.E.; Gottlieb, O.R.; Goulart, M.O.F.; De Lima, R.A.; Sant'ana, A.E.G. (1980). Potentially-antimicrobial canthinones from a Brazilian Simarouba plant. Ciênc. e Cult. 32, 117119.

12. Guarim Neto, G. (1987). Plantas medicinais utilizadas na medicina popular do Estado de Mato Grosso. Brasília, Brazil: MCT/CNPq.

13. Kaplan, M.A.; Figueiredo, M.R.; Gottlieb, O.R. (1994). Chemical diversity of plants from Brazilian Cerrados. An. Acad. Bras. Ciênc. 66, 49-54.

14. Lemes, R.M.L.; Lyon, J.P.; Moreira, L.M.; Resende, M.A. (2010). Antifungal susceptibility profile of Trichosporon isolates: correlation between CLSI and etest methodologies. Braz. J. Microbiol. 41, 310-315.

15. Mahady, G.B. (2005). Medicinal plants for the prevention and treatment of bacterial infections. Curr. Pharm. Design. 19, 2405-2423.

16. Manabe, H.; Sakagami, H.; Ishizone, H.; Kusano, H.; Fujimaki, M.;
Wida, C.; Komatsu, N.; Nakashima, H.; Murakami, T.; Yamamoto, N. (1992). Effects of catuaba extracts on microbial and HIV infection. In Vivo 6, 161-165.

17. Marqui, S.R.; Lemos, R.B.; SANTOS, L.A.; Castro-Gamboa, I.; Cavalheiro, A.J.; Bolzani, V.S.; Silva, D.H.S.; Scorzoni, L.; FuscoAlmeida, A.M.; Mendes-Giannini, M.J.S.; Young, M.C.M.; Torres, L.M.B. (2008). Saponinas antifúngicas de Swartzia langsdorffii. Quim. Nova 31, 828-831.

18. Mc Laughlin, J.L. (2008). Paw paw and cancer: Annonaceous acetogenins from discovery to commercial products. J. Nat. Prod. 71, 1311-21 and references cited therein.

19. Meyer, B.N.; Ferrigni, N.R.; Putnam, J.E.; Jacobsen, L.B.; Nichols, D.E.; McLaughlin, J.L. (1982). Brine shrimp - a convenient general bioassay for active-plant constituents. Plant. Med. 45, 31-34.

20. Nascimento, G.G.F.; Locatelli, J.; Freitas, P.C.; Silva, G.L. Antibacterial activity of plants extracts and phytochemicals on antibioticresistant bacteria (2000). Braz. J. Microbiol. 31, 247-256.

21. NCCLS (2002) Reference Method for Broth Dilution Antifungal Susceptibility Testing of Yeasts. Approved Standards M27-A2. National Committee for Clinical Laboratory Standards. Vol. 22, second ed., Wayne, PA.

22. NCCLS (2003) Methods for Dilution Antimicrobial Susceptibility Tests for Bacteria that Grow Aerobically. Approved Standards M7-A6. National Committee for Clinical Laboratory Standards. Vol. 22, Wayne, PA.

23. Newman, D.J.; Cragg, G.M. (2007). Natural products as sources of new drugs over the last 25 years. J. Nat. Prod. 70, 461-477 and references cited therein.

24. Oliveira, C.M.A.; Silva, M.R.R.; Kato, L.; Silva, C.C.; Ferreira, H.D.; Souza, L.K.H. (2004). Chemical composition and antifungal activity of the essential oil of Hyptis ovalifolia Benth. (Lamiaceae). J. Braz. Chem. Soc. $15,756-59$.

25. Ostrosky, E.A.; Mizumoto, M.K.; Lima, M.E.L.; Kaneko, T.M.; Nishikawa, S.O.; Freitas, B.R. (2008). Métodos para avaliação da atividade antimicrobiana e determinação da concentração inibitória mínima. Rev. Bras. Farmacog. 18, 301-307.

26. Somavilla, N.S. (1998). Utilização de plantas medicinais por uma comunidade garimpeira do sudoeste mato-grossense. Cuiabá, Brasil, 104p. (M.Sc. Dissertation. Instituto de Saúde Coletiva. UFMT). 